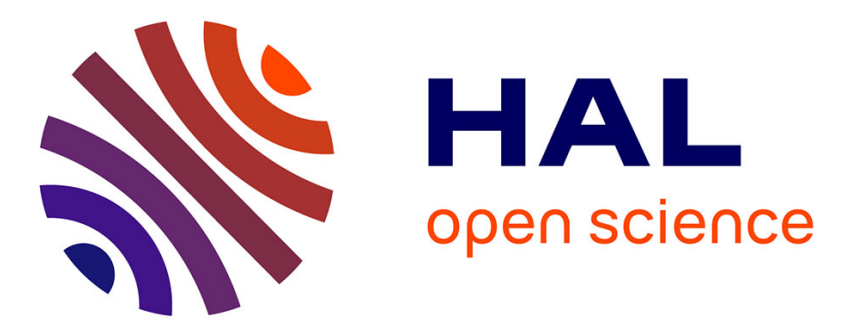

\title{
Travel medicine consultation: An opportunity to improve coverage for routine vaccinations
}

Y.T. Aba, A. Gagneux-Brunon, C. Andrillat, P. Fouilloux, F. Daoud, C. Defontaine, F. Lucht, E. Botelho-Nevers

\section{- To cite this version:}

Y.T. Aba, A. Gagneux-Brunon, C. Andrillat, P. Fouilloux, F. Daoud, et al.. Travel medicine consultation: An opportunity to improve coverage for routine vaccinations. Médecine et Maladies Infectieuses, 2019, 49, pp.257 - 263. 10.1016/j.medmal.2018.11.008 . hal-03486855

\section{HAL Id: hal-03486855 \\ https://hal.science/hal-03486855}

Submitted on 20 Dec 2021

HAL is a multi-disciplinary open access archive for the deposit and dissemination of scientific research documents, whether they are published or not. The documents may come from teaching and research institutions in France or abroad, or from public or private research centers.
L'archive ouverte pluridisciplinaire HAL, est destinée au dépôt et à la diffusion de documents scientifiques de niveau recherche, publiés ou non, émanant des établissements d'enseignement et de recherche français ou étrangers, des laboratoires publics ou privés.

\section{(ㅇ)(1) $\$$}

Distributed under a Creative Commons Attribution - NonCommerciall 4.0 International 


\section{Travel medicine consultation: an opportunity to improve coverage for routine vaccinations}

\section{La consultation de médicine du voyage : l'opportunité d'améliorer la couverture pour les vaccins de routine}

YT Aba ${ }^{1,2,4^{*}}$, A Gagneux-Brunon ${ }^{1,3,4^{*}}$, C Andrillat ${ }^{1}$, P Fouilloux ${ }^{1,3}$, F Daoud $^{1}$, C Defontaine $^{1}$, F Lucht $^{1,3,4}$, E Botelho-Nevers ${ }^{1,3,4}$

${ }^{1}$ Service des maladies infectieuses et tropicales, Centre de vaccinations internationales et conseils aux voyageurs, CHU de Saint-Etienne, France

${ }^{2}$ Service de santé publique et de maladies infectieuses, Université Alassane Ouattara, Bouaké, Côte d'Ivoire ${ }^{3}$ Inserm, CIC 1408, St-Etienne, France et Inserm, F-CRIN, Innovative clinical research network in vaccinology (I-REIVAC), Paris, France

${ }^{4}$ Groupe Immunité des Muqueuses et Agents Pathogènes - GIMAP EA 3064, Université de Saint-Etienne, Université de Lyon, France

*These co-authors equally contributed to the work.

Corresponding author: Amandine Gagneux-Brunon (MD, Ph-D) Tel: +33 4771208 13, Fax number: +33 4771209 93, amandine.gagneux-brunon@chu-st-etienne.fr

This work was presented at the $2015 \mathrm{JNI}$.

Mots clés : vaccins, vaccination des voyageurs, couverture vaccinale Keywords: vaccines, vaccination of travelers, vaccine coverage 


\section{Résumé}

Introduction. Les voyageurs peuvent être à l'origine de la diffusion de maladies transmissibles à prévention vaccinale au retour. Les médecins du voyage et médecins généralistes pourraient jouer un rôle majeur en contrôlant et en mettant à jour les vaccins de routine. L'objectif était de mesurer la couverture vaccinale (CV) des voyageurs consultant au centre de vaccination internationale (CVI).

Méthodes. La CV a été mesurée en référence au calendrier vaccinal en vigueur en France du $1^{\text {er }}$ août 2013 au 31 juillet 2014, chez les voyageurs présentant un certificat de vaccination.

Résultats. Parmi 2316 voyageurs ayant consulté au CVI, 2019 ont participé à l'étude et $1216(60,9 \%)$ ont fourni un certificat de vaccination. Les voyageurs disposant d'un certificat de vaccination étaient plus jeunes que ceux sans certificat (âge moyen $34,8 \pm 17,8$ vs $46 \pm$ $18,4$ ans, $p<0,0053)$ et étaient moins souvent des pèlerins à La Mecque. La CV pour le DTP était de $91,8 \%, 78,6 \%$ pour le ROR, et $59,4 \%$ pour l'hépatite $B$, lorsque celles-ci étaient indiquées. Le BCG avait été réalisé chez $71,9 \%$ des voyageurs. Un plus jeune âge était associé à une meilleure observance des recommandations sauf pour l'hépatite $B$, les voyageurs vaccinés étaient plus âgés que les non vaccinés.

Conclusion. Obtenir des informations sur le statut vaccinal des voyageurs est difficile. La CV pour les vaccins de routine devrait être améliorée dans cette population. Une consultation avant un voyage constitue une occasion de mettre à jour les vaccinations de routine. 


\section{Abstract}

Background. Travelers may be responsible for the spread of vaccine-preventable diseases upon return. Travel physicians and family physicians may play a role in checking and updating vaccinations before traveling. Our aim was to evaluate the vaccine coverage for mandatory and recommended vaccination in travelers attending a travel medicine clinic (TMC).

Methods. Vaccine coverage was measured using the current French immunization schedule as reference for correct immunization, in travelers providing a vaccination certificate during the TMC visit (University Hospital of Saint-Etienne), between August 1, 2013 and July 31, 2014.

Results. 2,336 travelers came to the TMC during the study period. Among the 2,019 study participants, only $1,216(60.3 \%)$ provided a vaccination certificate. Travelers who provided a vaccination certificate were significantly younger than travelers who did not (mean age: 34.8 \pm 17.8 vs $46 \pm 18.4$ years, $p<0.005$ ) and were less likely to be Hajj pilgrims. Vaccine coverage against Tetanus, Diphtheria, and Poliomyelitis (Td/IPV vaccine) was $91.8 \%, 78.6 \%$ against Measles, Mumps, and Rubella (MMR), and 59.4\% against Viral Hepatitis B (HBV). BCG vaccine coverage was $\mathbf{7 1 . 9 \%}$. Older travelers were less likely to be correctly vaccinated, except against HBV as vaccinated travelers were significantly older than unvaccinated travelers.

Conclusion. Obtaining information about immunization in travelers is difficult. Coverage for routine vaccines should be improved in this population. Travel medicine consultations could be the opportunity to vaccinate against MMR, HBV, and Td/IPV. 


\section{Background}

A total of 1,186 billion people travelled abroad in 2015 and the number of travelers should reach 1.8 billion a year in 2030 [1]. Travel medicine focuses on the health of travelers visiting foreign countries by preventing infectious diseases such as malaria, traveler's diarrhea, or yellow fever and giving health advice for personal safety as described in the Infectious Diseases Society of America guidelines [2]. Travelers may be responsible for the spread of vaccine-preventable diseases upon return [3]. Data on traveler's immunization prior to travel for vaccines mandatory or recommended in the general population remains scarce [4]. We previously observed that few travelers attending a travel medicine clinic (TMC) seek pretravel health advice from their family physician (FP) [5]. Consequently, travel physicians may play a role in checking correct immunizations against vaccine-preventable diseases such as mandatory and recommended vaccines in the general population. We performed a study in our TMC to evaluate the ability of travel physicians to obtain accurate information about immunization, and to determine in travelers seeking pre-travel health advice the vaccine coverage against Tetanus, Diphtheria, Poliomyelitis (Td-IPV), Measles, Mumps, Rubella (MMR), Hepatitis B (HBV), and tuberculosis, considered here as routine vaccines as nonspecific to the travel.

\section{Methods}

We conducted a cross-sectional study. All travelers who attended the TMC (University Hospital of Saint-Etienne, France) were proposed to participate in the study between August 1, 2013 and July 31, 2014. Demographic data and travel characteristics were collected using an anonymous self-administered questionnaire. Vaccination coverage for Td-IPV, HBV, MMR, and Bacillus Calmette-Guérin (BCG) vaccinations were checked by three physicians 
using health booklets and/or vaccination certificates provided by the travelers at the consultation. Complete (for HBV, MMR, and BCG) and up-to-date (for Td-IPV) immunization was defined as per the national immunization schedule during the investigational period [6]. Immunization against diphtheria and tetanus is mandatory for children under 18 months; immunization against poliomyelitis is mandatory for children aged under 13 years; the TdIPV vaccine is recommended in adults (with a booster at 25, 45, 65 years, and every 10 years after 65 years); the BCG vaccine was mandatory and became optional for people born after 2007; the MMR vaccine is recommended for people born after 1981 (two doses, and one dose in non-immune women of childbearing age); and the HBV vaccine (three doses) is recommended for people born after 1979. SPSS version 24.0 software 70 (24.0 Statistics IBM, Armonk, New York, NY) was used for the statistical analysis. The chi-square test and Fisher's exact test were used to compare the proportions with a $5 \%$ significance threshold $(p<0.05)$. To assess the precision of estimates for vaccine coverage in travelers with a vaccination certificate, we used a confidence interval of $95 \%(95 \% \mathrm{Cl})$. In the multivariate analysis, all variables with $p<0.02$ in the univariate analysis were included in the regression model. Our institution ethical committee approved the study.

\section{Results}

A total of 2,336 travelers attended the TMC during the study period. Overall, 2,019 of them (86.4\%) answered the survey. General characteristics of travelers attending the TMC are detailed in Table 1. A total of 1,216 (60.2\%) travelers provided their vaccination certificate or booklet at the consultation. Travelers who provided a proof of vaccination were significantly younger than those who did not (mean age $34.8 \pm 17.8$ vs $46 \pm 18.4$ years, $p<0.005$ ). Hajj 
pilgrims were less likely to bring a vaccination certificate at the TMC than other travelers. Only 60 of them (15.7\%) provided a vaccination certificate $(p<0.005)$.

The analysis of vaccine coverage was performed using the data of patients who provided a vaccination certificate. Vaccine coverage for Td-IPV, MMR, HBV, and BCG vaccine were respectively $91.8 \%, 78.6 \%, 59.4 \%$, and $69.1 \%$. Factors associated with a complete or an upto-date vaccination in univariate analysis are detailed in Table 2. Vaccine coverage did not differ according to the reason for travel except for Hajj pilgrimage. In multivariate analysis, only older age was significantly associated with the absence of correct immunization with the Td-IPV vaccine $(p<0.005)$. In multivariate analysis, only younger age was associated with correct immunization with the MMR vaccine $(p<0.005)$. Seventy-two travelers born before the implementation of the general recommendation for immunization against MMR were vaccinated against MMR (12.97\% of travelers with a vaccination certificate), 48 of them (66.7\%) were women with a mean age of $40.7 \pm 8.9$ years. In multivariate analysis, older age and female gender were significantly associated with correct immunization against HBV in travelers born after the implementation of recommendations in the general population ( $p<0.005$ and $p=0.013$, respectively). A total of 245 travelers not included in the population targeted by the general recommendation for the HBV vaccine, were vaccinated $(46.8 \%$ of travelers with a vaccination certificate and born before 1979). Consequently, the global vaccine coverage against HBV in our cohort of travelers was $54.03 \%$. A previous visit to the TMC was associated with HBV vaccine uptake in this population. Vaccine coverage increased to $56.7 \%$ in travelers who had ever sought pre-travel health advice at the TMC $(p=0.038$ in comparison with travelers visiting the TMC for the first time). A previous consultation to the TMC was not associated with better vaccine coverage for the BCG, Td-IPV, and MMR vaccines. In multivariate analysis, older age and traveling for the Hajj pilgrimage were 
significantly associated with the absence of immunization with the BCG vaccine $(p<0.005$ for each variable). Thirty-two travelers born after the end of mandatory immunization against tuberculosis received the BCG vaccine. Pre-travel consultation with a FP had no impact on vaccine coverage.

\section{Discussion}

As travelers may be a source of re-emergence of vaccine-preventable diseases [3], checking the immunization status in this population is crucial. A total of 213 centers for international vaccinations and/or TMC are implemented in France. Although our TMC is mainly devoted to immunization against Yellow fever, meningococcal disease, and Japanese encephalitis, only $60 \%$ of study participants came to our TMC with a vaccination certificate. Although the benefit of electronical medical records to measure vaccine coverage and to obtain immunization status remains unclear [7], the general use of web-based tools to report vaccine status might circumvent difficulties to obtain information about immunization.

With regard to the Td-IPV vaccine, we observed high vaccine coverage as compared with vaccine coverage among the French general population [8] and previously published studies of travelers in France $[4,9,10]$. Td-IPV vaccine coverage was particularly low among Hajj pilgrims - an older population in this cohort - with significantly more chronic diseases and a low rate of pre-travel consultation with a FP, as reported previously [5]. Most Hajj pilgrims were probably foreign born and not targeted by the French immunization schedule. This may partly explain the low vaccine coverage observed in this population. Many Hajj pilgrims who sought pre-travel health advice in our TMC during the study period also did not provide a vaccination certificate. Td-IPV vaccine coverage decreased with age; this observation was previously made in the general population in other countries [11-13]. Cases of travel- 
associated tetanus, diphtheria, poliomyelitis were described [14]. Updating immunizations against these diseases in travelers is crucial, particularly in elderly travelers. The observed MMR vaccine coverage is close to the coverage observed in the French general population [15]. The United States recommend immunization of travelers against measles [16], whereas immunization in France should be individually discussed [17]. Travelers may be a source of measles outbreaks upon return $[3,18,19]$. Increasing the MMR vaccine coverage in travelers is crucial. A recent study performed in the United States demonstrated that unvaccinated American international travelers were more likely to be the source of outbreaks than unauthorized migrants to the United States upon return [20]. Serological testing in travelers might be recommended to identify travelers requiring vaccination [21]. HBV vaccine coverage in travelers is similar to that of the general population in France [15] and higher than previously reported in another French cohort of travelers [4]. In contrast with other vaccines, older age was associated with a greater vaccine coverage. Our analysis is limited to travelers born after 1979. The oldest participants were the target of a wide campaign of immunization in France during the 1994-1998 period, which was suddenly stopped. This modification in guidelines resulted in an increased number of susceptible adults and after a decrease in HBV infection incidence, a new increase in HBV infection incidence in French young adults is highly probable [22]. Serological testing for HBV may help identify travelers requiring vaccination. A previous study reported that $35 \%$ of travelers (seeking pre-travel health advice in a French TMC) had serological markers for chronic hepatitis B or resolved hepatitis B [23]. The prevalence of HBV infection or past infection is associated with the country of origin of travelers [23], and it is limited to $5.2 \%$ in travelers born in France. No data is available on HBV serology in travelers seeking pre-travel health advice in our TMC. In 2013 the HBV vaccine was recommended in travelers planning a long stay in countries where 
the prevalence of $\mathrm{HBV}$ is $\mathbf{2} \%$. Most travelers seeking health advice in our TMC were traveling to East Asia, the Middle East, Africa, and South America, where the HBV infection is highly prevalent. The mean length of stay abroad was 3.25 weeks. We surprisingly observed a low vaccine coverage with the BCG vaccine even though the vaccine was mandatory in France until 2007. BCG vaccination was administered in early infancy and proof of vaccination might be lost. Mandatory BCG vaccination also did not concern people born abroad. Immunization with the BCG vaccine is recommended in travelers aged below 15 years who are travelling to regions with a high incidence of TB.

Travel physicians should play a crucial role in checking and improving coverage for nationally recommended vaccines in travelers, as we did not observe any association between seeking pre-travel health advice from FPs and better immunization and as international travels facilitate the spread of communicable diseases. However, FPs have an important role in pretravel advice [2] and should seize this opportunity to vaccinate patients. However, vaccine hesitancy is highly common in the general population and also affects FPs [24,25]. Immunizing travelers with mandatory vaccines for traveling and with non-mandatory vaccines may then be challenging. Aubry et al. reported that only $55.9 \%$ of travelers unvaccinated against Td-IPV and 6\% of travelers unvaccinated against HBV were vaccinated at the TMC [4]. A recent study performed in the United States reported that $16 \%$ of travelers required MMR vaccination, but almost half of them refused to be vaccinated [26]. Both observations highlight difficulties to reinforce travelers' compliance with immunization guidelines. New tools to promote vaccinations in TMCs are required. Developing decision aids for vaccinations may increase acceptance of vaccinations among travelers.

Our study has several limitations. First, we only measured vaccine coverage in travelers who provided a proof of vaccination at the time of the TMC visit. As travelers who provided a 
vaccination certificate were younger and as vaccine coverage decreased with age, the observed vaccine coverage was probably slightly overestimated. Aubry et al. observed lower vaccine coverage for Td-IPV, but they took into consideration self-reported information by travelers in their analysis [4]. Self-reported vaccine uptake may lead to an overestimation of vaccine coverage [27]. Secondly, as approximately $20 \%$ of travelers attending our TMC were aged above 60, and did not have serological makers, it was difficult to evaluate natural immunization. Consequently, we restrained the analysis of vaccine coverage to travelers targeted by French general recommendations for vaccinations [28]. We also did not collect data on pertussis, but traveling adults might be responsible for the spread of this disease [29]. Moreover, vaccine coverage was only estimated in travelers seeking pre-travel health advice at the TMC, which may not reflect the vaccine coverage in all travelers. Only travelers who required immunization against yellow fever, Neisseria meningitidis, or Japanese encephalitis consulted at our TMC. However, collecting information about immunization at the airport boarding gate may circumvent this bias, but it is limited by difficulties to collect reliable information - vaccination certificate - about immunization. Third, we did not collect information about vaccination after the TMC visit. Consequently, we could not measure the impact of the visit to the TMC on vaccine acceptance in travelers.

\section{Conclusion}

This study highlights difficulties in obtaining reliable information about immunization in France and notably in travelers. Developing innovative tools to collect information about immunization is crucial. Moreover, travel physicians should check the history of immunization with routine vaccines, and not only travel-related vaccines, to improve vaccine coverage among travelers who represent an increasing part of the general population. 


\section{Acknowledgments}

We would like to thank Glyn Thoiron for English editing.

\section{Authors' contribution}

$\mathrm{CA}$ and EBN designed the research.

YTA, AGB, and CA performed the statistical analysis.

$\mathrm{PF}, \mathrm{CD}, \mathrm{FD}$, and $\mathrm{CA}$ collected the data.

YTA, AGB, EBN, and FL wrote the article. 


\section{Declaration of interests}

The authors declare no competing interests. 


\section{References}

[1] Faits saillants OMT du tourisme - Édition 2016 | World Tourism Organization n.d. http://www.e-unwto.org/doi/book/10.18111/9789284418169 (accessed February 28, 2017).

[2] Hill DR, Ericsson CD, Pearson RD, Keystone JS, Freedman DO, Kozarsky PE, et al. The Practice of Travel Medicine: Guidelines by the Infectious Diseases Society of America. Clin Infect Dis 2006;43:1499-539. doi:10.1086/508782.

[3] Gautret P, Botelho-Nevers E, Brouqui P, Parola P. The spread of vaccine-preventable diseases by international travellers: a public-health concern. Clin Microbiol Infect Off Publ Eur Soc Clin Microbiol Infect Dis 2012;18 Suppl 5:77-84. doi:10.1111/j.14690691.2012.03940.x.

[4] Aubry C, Gaudart J, Gaillard C, Delmont J, Parola P, Brouqui P, et al. Demographics, health and travel characteristics of international travellers at a pre-travel clinic in Marseille, France. Travel Med Infect Dis 2012;10:247-56. doi:10.1016/j.tmaid.2012.09.004.

[5] Gagneux-Brunon A, Andrillat C, Fouilloux P, Daoud F, Defontaine C, Charles R, et al. Pretravel advice seeking from GPs by travellers with chronic illness seen at a travel clinic. J Travel Med 2016;23. doi:10.1093/jtm/taw013.

[6] Ministère des affaires sociales et de la santé. Calendrier des vaccinations et recommandations vaccinales $2014 \quad$ n.d. http://socialsante.gouv.fr/IMG/pdf/Calendrier_vaccinal_ministere_sante_2014-2.pdf (accessed March 9, 2017). 
[7] Rolnick SJ, Parker ED, Nordin JD, Hedblom BD, Wei F, Kerby T, et al. Self-report compared to electronic medical record across eight adult vaccines: do results vary by demographic factors? Vaccine 2013;31:3928-35. doi:10.1016/j.vaccine.2013.06.041.

[8] Guthmann JP. Enquête nationale de couverture vaccinale, France, janvier 2011. Couverture vaccinale contre la grippe saisonnière dans les groupes cibles et mesure de l'efficacité vaccinale. Couverture vaccinale par les vaccins diphtérie-tétanospoliomyélite (dTP) et antipneumococcique chez les personnes âgées de 65 ans et plus. n.d.

[9] Lee VJ, Wilder-Smith A. Travel characteristics and health practices among travellers at the travellers' health and vaccination clinic in Singapore. Ann Acad Med Singapore 2006;35:667-73.

[10] Chinwa Lo S, Mascheretti M, Chaves T do SS, Lopes MH. [Travelers' vaccinations: experience from the Travelers' Clinic of Hospital das Clínicas, University of São Paulo School of Medicine]. Rev Soc Bras Med Trop 2008;41:474-8.

[11] Guthmann J-P, Fonteneau L, Antona D, Lévy-Bruhl D. [Factors associated with tetanus vaccination coverage in adults in France and with knowledge of vaccination status]. Med Mal Infect 2010;40:560-7. doi:10.1016/j.medmal.2010.03.009.

[12] Bovier PA, Chamot E, Bouvier Gallacchi M, Loutan L. Importance of patients' perceptions and general practitioners' recommendations in understanding missed opportunities for immunisations in Swiss adults. Vaccine 2001;19:4760-7.

[13] Skowronski DM, Pielak K, Remple VP, Halperin BA, Patrick DM, Naus M, et al. Adult tetanus, diphtheria and pertussis immunization: knowledge, beliefs, behavior and anticipated uptake. Vaccine 2004;23:353-61. doi:10.1016/j.vaccine.2004.05.033. 
[14] Gautret P, Wilder-Smith A. Vaccination against tetanus, diphtheria, pertussis and poliomyelitis in adult travellers. Travel Med Infect Dis 2010;8:155-60. doi:10.1016/j.tmaid.2010.02.007.

[15] Couverture vaccinale en France en 2014: un bilan ... - MesVaccins.net n.d. https://www.mesvaccins.net/web/news/6140-couverture-vaccinale-en-france-en2014-un-bilan-contraste (accessed March 3, 2017).

[16] Prevention of Measles, Rubella, Congenital Rubella Syndrome, and Mumps, 2013 n.d. https://www-cdc-gov.gate2.inist.fr/mmwr/preview/mmwrhtml/rr6204a1.htm (accessed March 3, 2017).

[17] BEH hors-série - Recommandations sanitaires pour les voyageurs, 2016 / 2016 / Archives / BEH - Bulletin épidémiologique hebdomadaire / Publications et outils / Accueil n.d. http://invs.santepubliquefrance.fr//fr/Publications-et-outils/BEH-Bulletinepidemiologique-hebdomadaire/Archives/2016/BEH-hors-serie-Recommandationssanitaires-pour-les-voyageurs-2016 (accessed March 3, 2017).

[18] MacIntyre CR, Karki S, Sheikh M, Zwar N, Heywood AE. The role of travel in measles outbreaks in Australia - An enhanced surveillance study. Vaccine 2016;34:4386-91. doi:10.1016/j.vaccine.2016.07.023.

[19] Nic Lochlainn L, Mandal S, de Sousa R, Paranthaman K, van Binnendijk R, Ramsay M, et al. A unique measles B3 cluster in the United Kingdom and the Netherlands linked to air travel and transit at a large international airport, February to April 2014. Euro Surveill Bull Eur Sur Mal Transm Eur Commun Dis Bull 2016;21. doi:10.2807/15607917.ES.2016.21.13.30177. 
[20] Bednarczyk RA, Rebolledo PA, Omer SB. Assessment of the role of international travel and unauthorized immigration on measles importation to the United States. J Travel Med 2016;23. doi:10.1093/jtm/taw019.

[21] Turner DP, McGuinness SL, Cohen J, Waring L, Leder K. Use of pre-travel vaccinepreventable disease serology as a screening tool to identify patients in need of pretravel vaccination: a retrospective audit. J Travel Med 2017;24. doi:10.1093/jtm/tax011.

[22] Ramière C, Roche L, Scholtès C, Iwaz J, Saison J, Ecochard R, et al. Evolution of the incidence of hepatitis B virus infection and immunization rates in a large French cohort born between 1960 and 1994. Clin Microbiol Infect Off Publ Eur Soc Clin Microbiol Infect Dis 2016;22:889.e1-889.e7. doi:10.1016/j.cmi.2016.07.014.

[23] Gergely A, Bechet S, Goujon C, Benabdelmoumen G, Consigny P-H. Hepatitis B screening in travelers: A retrospective analysis. Travel Med Infect Dis 2014;12:707-12. doi:10.1016/j.tmaid.2014.07.003.

[24] Larson HJ, de Figueiredo A, Xiahong Z, Schulz WS, Verger P, Johnston IG, et al. The State of Vaccine Confidence 2016: Global Insights Through a 67-Country Survey. EBioMedicine 2016;12:295-301. doi:10.1016/j.ebiom.2016.08.042.

[25] Killian M, Detoc M, Berthelot $P$, Charles R, Gagneux-Brunon A, Lucht F, et al. Vaccine hesitancy among general practitioners: evaluation and comparison of their immunisation practice for themselves, their patients and their children. Eur J Clin Microbiol Infect Dis Off Publ Eur Soc Clin Microbiol 2016. doi:10.1007/s10096-0162735-4.

[26] Hyle EP, Rao SR, Jentes ES, Fiebelkorn AP, Hagmann SHF, Walker AT, et al. Missed Opportunities for Measles, Mumps, Rubella Vaccination Among Departing U.S. Adult 
Travelers Receiving Pretravel Health Consultations. Ann Intern Med 2017. doi:10.7326/M16-2249.

[27] Jiménez-García R, Hernandez-Barrera V, Rodríguez-Rieiro C, Carrasco Garrido P, López de Andres A, Jimenez-Trujillo I, et al. Comparison of self-report influenza vaccination coverage with data from a population based computerized vaccination registry and factors associated with discordance. Vaccine 2014;32:4386-92. doi:10.1016/j.vaccine.2014.06.074.

[28] Calendrier vaccinal - Préserver sa santé - Ministère des Affaires sociales et de la Santé n.d. http://social-sante.gouv.fr/prevention-en-sante/preserver-sa-sante/calendriervaccinal (accessed March 3, 2017).

[29] Gómez-Junyent J, Calvo-Cano A, Muñoz J, Gascón J. Bordetella pertussis infection among international travellers: The need for a rigorous implementation of vaccine policies. Travel Med Infect Dis 2015;13:259-60. doi:10.1016/j.tmaid.2015.03.011. 
Table 1. Demographical characteristics of the 2,019 travelers who completed the questionnaire and of the 1,216 travelers who provided vaccination certificate (with percentages of the overall study participants), and vaccine coverage for the Td-IPV, MMR, HBV, and BCG vaccines

Tableau 1. Caractéristiques démographiques des 2019 voyageurs ayant répondu au questionnaire et des 1216 voyageurs ayant fourni leur certificat de vaccination (avec pourcentages de l'ensemble des participants) et couverture vaccinale pour le DTP, ROR, VHB et BCG

\begin{tabular}{|c|c|c|}
\hline Findings & $\begin{array}{l}\text { Data on travelers } \\
\qquad(\mathrm{N}=2,019)\end{array}$ & $\begin{array}{c}\text { Characteristics of } \\
\text { travelers with a } \\
\text { vaccination certificate } \\
\text { ( } N=1,216,60.2 \% \text { of the } \\
\text { overall study participants) }\end{array}$ \\
\hline Mean age (years) & $39.4( \pm 18.9)$ & $34.8 \pm 17.8$ \\
\hline Male gender & $1,039(51.4)$ & $590(56.8)$ \\
\hline \multicolumn{3}{|l|}{ Reason for travel } \\
\hline Tourism & $829(41.1)$ & $593(71.5)$ \\
\hline Hajj & $388(19.2)$ & $61(15.7)$ \\
\hline $\begin{array}{l}\text { Visiting friends and } \\
\text { relatives }\end{array}$ & $288(14.3)$ & $198(68.7)$ \\
\hline Humanitarian mission & 199 (9.9) & $160(80.4)$ \\
\hline Job opportunity & $145(7.2)$ & $98(67.5)$ \\
\hline International study & $46(2.3)$ & $40(87.9)$ \\
\hline Other or data unavailable & $124(6.1)$ & $66(53.2)$ \\
\hline Length of travel & $3.25( \pm 2.18)$ & $3.05 \pm 1.78$ \\
\hline Chronic illness & $391(19.4)$ & $198(50.6)$ \\
\hline \multicolumn{3}{|l|}{ Td-IPV vaccine } \\
\hline Recommended vaccine & $2,019(100)$ & $1,216(60.2)$ \\
\hline Correct immunization & & $1,116(55.3)$ \\
\hline Td-IPV vaccine coverage & & $91.8 \%(95 \% \mathrm{Cl} 91-94)$ \\
\hline \multicolumn{3}{|l|}{ MMR vaccine } \\
\hline Recommended vaccine & $843(41.7)$ & $635(75.3)$ \\
\hline Correct immunization & & $499(59.1)$ \\
\hline MMR vaccine coverage & & $78.6 \%(95 \% \mathrm{Cl} 73-80)$ \\
\hline \multicolumn{3}{|l|}{ HBV vaccine } \\
\hline Recommended vaccine & $946(46.9)$ & $693(73.2)$ \\
\hline Correct immunization & & $412(43.5)$ \\
\hline HBV vaccine coverage & & $59.4 \%(95 \% \mathrm{Cl} 56-63)$ \\
\hline \multicolumn{3}{|l|}{ BCG vaccine } \\
\hline Recommend vaccines & ND & $1,216(60.2)$ \\
\hline Correct immunization & & $874(43.2)$ \\
\hline BCG vaccine coverage & & $71.9 \%(95 \% \mathrm{Cl} 69-74)$ \\
\hline
\end{tabular}


$\mathrm{n}(\%)$ for categorical variables and mean ( \pm SD and range) for continuous variable (ND: not determined) and $95 \% \mathrm{Cl}$ for vaccine coverage (calculated in travelers providing a vaccination certificate; chronic illness included hypertension, diabetes mellitus, cancer, history of cardiovascular disease, dyslipidemia, respiratory diseases, chronic obstructive pulmonary disease, asthma, obstructive sleep apnea, thyroid disease, HIV infection, autoimmune diseases) 
Table 2. Factors associated with correct immunization in travelers attending the TMC and providing a vaccination certificate

Tableau 2. Facteurs associés à une immunisation à jour chez les voyageurs consultant au centre de vaccination internationale et fournissant un certificat de vaccination

\begin{tabular}{|c|c|c|c|c|c|c|c|c|c|c|c|c|}
\hline & & Td-IPV & & & MMR* & & & $\mathrm{HBV}^{* *}$ & & & $\mathrm{BCG} * * *$ & \\
\hline & $\begin{array}{c}\text { Vaccinate } \\
d(n= \\
1,120)\end{array}$ & $\begin{array}{l}\text { Unvaccinate } \\
\qquad d(n=96)\end{array}$ & $p$ & $\begin{array}{l}\text { Vaccinated } \\
(n=485)\end{array}$ & $\begin{array}{l}\text { Unvaccinat } \\
\text { ed }(n=150)\end{array}$ & $p$ & $\begin{array}{l}\text { Vaccinate } \\
d(n=412)\end{array}$ & $\begin{array}{l}\text { Unvaccinated } \\
\qquad(n=281)\end{array}$ & $p$ & $\begin{array}{l}\text { Vaccinate } \\
d(n=874)\end{array}$ & $\begin{array}{c}\text { Unvaccina } \\
\text { ted } \\
(n=322)\end{array}$ & $p$ \\
\hline Age & $34.3 \pm 17.8$ & $40 \pm 16.4$ & 0.006 & $19.7 \pm 8.3$ & $24.2 \pm 7.3$ & $\begin{array}{c}<0.00 \\
5\end{array}$ & $22.9 \pm 9.4$ & $19.7 \pm 7.1$ & $\begin{array}{c}<0.00 \\
5\end{array}$ & $32.1 \pm 14.6$ & $\begin{array}{c}46.7 \pm \\
17.7\end{array}$ & $<0.005$ \\
\hline \multicolumn{13}{|l|}{ Gender } \\
\hline Male & $531(90)$ & $59(10)$ & 0.024 & $218(72.2)$ & $84(27.8)$ & 0.03 & 183 (55.6) & $129(36.2)$ & 0.013 & 424 (71.9) & $166(28.1)$ & 0.94 \\
\hline Female & 580 (94) & $37(6)$ & & 259 (79.7) & $66(20.3)$ & & $227(63.8)$ & $146(44.4)$ & & $444(72)$ & $173(28)$ & \\
\hline \multicolumn{13}{|c|}{$\begin{array}{l}\text { FP attendance } \\
\text { before TMC visit }\end{array}$} \\
\hline Yes & $134(88.1)$ & $16(10.5)$ & 0.056 & $27(65.8)$ & $14(34.1)$ & 0.045 & $26(56.5)$ & $20(43.5)$ & 0.114 & $86(56.6)$ & $66(43.4)$ & $<0.005$ \\
\hline No & 898 (92.7) & $71(7.3)$ & & 416 (76.6) & $127(23.4)$ & & $358(60.8)$ & 231 (39.2) & & 727 (75) & $242(25)$ & \\
\hline
\end{tabular}




\begin{tabular}{|c|c|c|c|c|c|c|c|c|c|c|c|c|}
\hline Hajj P & & & & & & & & & & & & \\
\hline Yes & $48(78.7)$ & $10(16.4)$ & \multirow{2}{*}{$\begin{array}{c}<0.00 \\
5\end{array}$} & $5(62.5)$ & $3(37.5)$ & \multirow[t]{2}{*}{0.35} & $6(60)$ & $4(40)$ & \multirow[t]{2}{*}{0.97} & $18(29.5)$ & $43(71.7)$ & \multirow[t]{2}{*}{$<0.005$} \\
\hline No & $\begin{array}{l}1,072 \\
(92.8)\end{array}$ & $83(7.2)$ & & $480(76.6)$ & $147(23.4)$ & & 406 (59.4) & $277(40.6)$ & & $856(74.1)$ & 299 (25.9) & \\
\hline
\end{tabular}

Td-IPV: Tetanus, Diphtheria, Poliomyelitis, MMR: Measles, Mumps, Rubella, HBV: Hepatitis B Virus, BCG: Calmette-Guérin Bacillus, FP: family physician (pre-travel health consultation with FP), $\mathrm{n}$ (\% of vaccinated or unvaccinated travelers in each predictor group) for categorical variables and mean ( \pm SD) for continuous variables. For 20 travelers, vaccination status for Td-IPV and BCG vaccines remained unclear (discrepancies between vaccination certificate and information given by the patient). *For people born after $1981, * *$ for people born after $1979, * * *$ for people born before 2007. 